\title{
A cross-sectional study on the microbiological quality and safety of raw chicken meats sold in Nairobi, Kenya
}

\author{
Joyce Arua Odwar ${ }^{1}$, Gideon Kikuvi ${ }^{1}$, James Ngumo Kariuki ${ }^{2}$ and Samuel Kariuki ${ }^{3 *}$
}

\begin{abstract}
Background: Chicken is a rich source of meat protein and is increasingly being consumed in urban areas in Kenya. However, under poor hygienic environment, raw chicken meat presents an ideal substrate supporting the growth of pathogenic Escherichia coli and Coliform bacteria indicating the potential presence of other pathogenic bacteria; this may constitute a major source of food-borne illnesses in humans. This study sought to assess the microbiological quality and safety of raw chicken meat sold in Nairobi, Kenya by determining the E. coli/coliform contamination levels as well as the antimicrobial resistance patterns and pathogenicity of $E$. coli isolated.
\end{abstract}

Findings: We conducted a Cross-sectional study to collect two hundred raw chicken samples that were randomly purchased between the periods of August 2011-February 2012. Enumeration of bacteria was done using $3 \mathrm{M}$ Petri film E. coli/Coliform count plates, isolation and identification of E. coli through standard cultural and biochemical testing, antimicrobial susceptibilities interpreted according to criteria set by the Clinical and Laboratory Standards Institute (2012) while Polymerase chain reaction assays were used to determine presence of virulence genes in isolated E. coli. Data was analyzed using SPSS version 17.0. Contamination rates were $97 \%$ and $78 \%$ respectively for Coliform bacteria and E. coli. Seventy six percent of samples fell under the unacceptable microbial count limit (>100 cfu/ml) and significant differences in the $E$. coli/coliform counts $(p<0.001)$ were observed among the chicken retail outlets with samples from supermarkets having the lowest level of contamination compared to the rest of the retail outlets. Seventy five percent of the isolates were resistant to at least one of the 12 antibiotics tested with resistance to tetracycline being the highest at $60.3 \%$. In addition $40.4 \%$ E. coli isolates were positive for the ten virulence genes tested.

Conclusion: Raw retail chicken meats in Nairobi are not only highly contaminated, but also with potentially pathogenic and multi-drug resistant strains of E. coli. It will be important for public health authorities and retail chicken processing outlets to collaborate in ensuring adherence to set out principles of hygienic processing and handling of chicken meats in order to reduce potential risks of infection.

Keywords: Raw retail chicken meat, E. coli/coliforms, Microbial counts

\section{Findings}

\section{Background}

Ensuring safe food supply has been one of the major challenges and concerns for producers, consumers and public health officials in both developing and developed countries. This is because foods excessively contaminated with pathogenic and spoilage micro-organism are undesirable and can cause food borne illnesses [1-3]. Such illnesses

\footnotetext{
*Correspondence: samkariuki2@gmail.com

${ }^{3}$ Centre for Microbiology Research, Kenya Medical Research Institute, P.O Box 43640-00100, Nairobi, Kenya

Full list of author information is available at the end of the article
}

cost billions of dollars in medical care and sometimes even result to death [4]. Several epidemiological reports have implicated foods from animal origin as major vehicles associated with illnesses caused by food borne pathogens [5-7]. Coliform bacteria, especially fecal coliforms, are good microbial indicators of the potential presence of disease causing bacteria and also show the general sanitary quality of the food. Food contamination by Escherichia coli is closely associated with fecal contamination. This is because $E$. coli are the most prevalent commensal enteric bacteria in animals and humans and are also important 
zoonotic agents that can be implicated in animal and human infectious diseases [8].

Raw or undercooked chicken meat is particularly prone to contamination. The microbiological quality of chicken meat as purchased by consumers depends mostly on; the slaughter process, sanitation during processing and packaging, maintenance of adequate cold chain storage from the processing to the retail level and to the consumer and finally sanitation during handling at the retail end [9-12]. Chicken meat can also act as a reservoir of drug resistant bacteria. Antimicrobial resistance among E. coli in food animals such as chicken is of increasing concern due to the potential for transfer of these resistant pathogens to the human population [13-15].

In urban areas such as Nairobi, marketing of chicken products is generally undertaken in retail outlets such as supermarkets, local butcheries located in different geosocio-economic status and even from street vendors in some low income settings. Public health research in countries such as the United States of America focusing on food qualities demonstrated that stores in low socio-economic status populations, because of a higher prevalence of food safety violations, were shown to be consistently exposed to food that is of lower microbial quality. Because of this access pattern, such populations are placed at increased risk of food-borne illnesses $[16,17]$. In Kenya, there is a paucity of data on coliform contamination and antimicrobial resistant $E$. coli in raw retail chicken supplied to retail outlets in the city. Studies related to antimicrobial resistant $E$. coli have been done on isolates from farm animals and chicken carcass samples from slaughter [18] but not from raw retail chicken which is made available to consumers. Furthermore, no studies are available on the contamination levels in chicken meat available to populations living in different socio-economic status yet, these data are essential for performing risk assessment and risk management for food safety. This study reports on the microbiological quality and safety of chicken meat available to populations who purchase from different retail outlets (supermarkets, retail outlets in high income areas, retail outlets in middle income areas and retail outlets in low income areas) in the city of Nairobi.

\section{Methods}

\section{Study area and sampling}

The study was conducted in Nairobi County. Nairobi is the administrative and commercial capital in Kenya and home to thousands of businesses including the retail chicken business.. There is a huge disparity in income levels and population densities in Nairobi. The people living in the western suburbs are generally the more affluent while the lower and middle-income populations dominate the eastern suburbs [19].
In a cross-sectional study, chicken samples were randomly purchased from August 2011 to February 2012 from different retail outlets spread over 28 locations in Nairobi. In order to take into account compounding factors of socio-economic status within Nairobi, the retail outlets where samples were purchased were classified into supermarkets, shops from high end areas (low densely populated, up-market residential suburbs), shops from middle end areas (middle densely populated areas further classified into high middle and low middle income areas) and shops from low end areas (densely populated slums and informal settings). Classification of locations into these groups was done based on a study on residential segregation in Nairobi [20]. A total of two hundred chicken samples $(n=39$, supermarkets; $n=39$ high end area retail outlets; $\mathrm{n}=84$, high middle end area retail outlets; $\mathrm{n}=20$, low middle end area retail outlets and $\mathrm{n}=18$, low end area retail outlets) were purchased. Both freshly slaughtered as well as samples that have been in storage in freezers were included in the study. Packaged chicken samples were transported in cool boxes to the laboratory for bacterial isolation within 1 hour from time of collection. Samples were processed at the Kenya Medical Research Institute, Centre for Microbiology Research laboratories, Kenyatta hospital compound. Ethical approval to perform this study was obtained from the Ethics Review Committee at Kenya Medical Research Institute, Reference SSC No. 2036.

\section{Bacteriological analysis}

Enumeration of $E$. coli and coliform bacteria from the chicken samples was performed as described in the Association of Analytical Communities International, official methods of analysis using $3 \mathrm{M}$ petrifilm $E$. coli/ Coliform count plates [21] with slight modification. The samples, which included the skin of the chicken along with the meat itself, were aseptically removed from the package and 100 gram piece of chicken was weighed and placed in $100 \mathrm{ml}$ sterile distilled water. One $\mathrm{ml}$ of the rinse water from the sample was placed onto the center of the bottom film and covered carefully avoiding entrapment of air bubbles and the plates from all samples incubated for $24 \pm 2 \mathrm{hrs}$ at $35^{\circ} \mathrm{C}$. Colony counts for each petrifilm were done the following day and the microbial count results converted to the base 10 logarithm of the number of colony forming units per $\mathrm{ml}(\mathrm{cfu} / \mathrm{ml})$ rinse water obtained from the samples. Typical E. coli colonies growing on the petrifilm were then selected and sub-cultured in MacConkey agar to obtain pure colonies. After a series of biochemical tests for confirmative identification [22], positive E. coli isolates were stored at $-80^{\circ} \mathrm{C}$ in trypticase soy broth for further antimicrobial susceptibility tests and PCR to determine the presence of virulence genes. 


\section{Antimicrobial susceptibility testing}

Using the Kirby-Bauer disc diffusion method [23], E. coli were tested for their susceptibility to 12 commonly used antimicrobials on disks containing; Ampicillin (AMP $10 \mu \mathrm{g}$ ), Amoxycillin-clavulanic acid (AMC, $30 \mu \mathrm{g}$ ), Tetracycline (TE $30 \mu \mathrm{g})$, sulphamethoxazole-trimethoprin (SXT $30 \mu \mathrm{g}$ ), Ciprofloxacin (CIP $5 \mu \mathrm{g}$ ), Ceftriaxone (CRO $30 \mu \mathrm{g})$, Ceftazidime (CAZ $30 \mu \mathrm{g})$, Kanamycin (K $30 \mu \mathrm{g}$ ), Streptomycin (S $10 \mu \mathrm{g})$, Gentamicin (CN $10 \mu \mathrm{g})$, Nalidixic acid (NA $30 \mu \mathrm{g}$ ) and Chloramphenicol (C $30 \mu \mathrm{g})$. The concentrations of the antimicrobial disks were selected based on the internationally recognized standards and guidelines on antimicrobial routine testing and reporting on enterobacteriaceae provided by the Clinical and Laboratory Standard Institute. E. coli strain 25922 was used to control for bacterial growth and potency of antibiotic disks. Inoculated agar plates were incubated at $37^{\circ} \mathrm{C}$ for $24 \mathrm{~h}$. The susceptibility zones were also measured and interpreted according to criteria set by the Clinical and Laboratory Standards Institute [24].

\section{Bacterial DNA extraction and detection of virulence genes} in E. coli

DNA from the isolated E. coli as well as from 5 control strains was extracted following the procedures described by Ehrt and Schnappinger [25], with slight modifications. A loop full of overnight bacterial culture was suspended in $1 \mathrm{ml}$ of sterile distilled water and then boiled for 10 minutes at $95^{\circ} \mathrm{C}$. The cell mixture was centrifuged for 5 minutes at 14,000 rpm and supernatant was used as the DNA template for PCR amplification. Ten PCR primers were used to detect the target genes enumerating toxins in pathogenic E. coli [26]. A multiplex PCR system was optimized by the progressive incorporation of primers corresponding to the different genes and several combinations of melting temperatures, primer concentrations and DNA template concentration. PuReTaq ready to go PCR beads (GE Health care) were used for PCR. The total reaction volume in each PCR tube was $25 \mu \mathrm{l}$ containing $3 \mu \mathrm{l}$ template DNA, $2 \mu \mathrm{l}$ primer $(0.2 \mu \mathrm{l}$ of each primer) and $20 \mu$ sterile PCR water. PCR was done under the following conditions; initial denaturation at $94^{\circ} \mathrm{C}$ for 5 minutes. This was followed by 35 cycles of denaturation at $94^{\circ} \mathrm{C}$ for 1 minute, annealing at $56^{\circ} \mathrm{C}$ for 30 seconds and extension at $72^{\circ} \mathrm{C}$ for 1 minute. The final step was amplification at $72^{\circ} \mathrm{C}$ for 10 minutes. Amplicons were then subjected to agarose gel electrophoresis and viewed under UV light.

\section{Statistical analysis}

Statistical analysis including means, medians and standard deviations, was conducted by means of SPSS version 17.0 software. To determine differences in microbial counts in chicken samples purchased from among the various retail outlets, ANOVA was used after converting the counts to base 10 logarithms. The chi-square test was used to assess any statistical significant association between antimicrobial resistances in the $E$. coli isolated with regard to retail outlet classification from where the raw chicken was purchased.

\section{Results}

\section{Contamination rate and microbial count in raw retail} chicken

Contamination rate of chicken samples by total coliform bacteria was found to be $97 \%$ while contamination by $E$. coli was $78 \%$. The average E. coli and coliform counts for all samples in general were observed to be above the acceptable range for E. coli counts as set by the Hazard Analysis and Critical Control Point system (HACCP), developed by Food and Agriculture Organization (FAO) and adopted by the Codex Alimentarius Commission (3.911 and 5.0261 $\log _{10} \mathrm{cfu} / \mathrm{ml}$ respectively). According to this system, the acceptable food safety range is $100 \mathrm{cfu} / \mathrm{ml}$ or less $\left(2.000 \log _{10} \mathrm{cfu} / \mathrm{ml}\right.$ or less), the marginal or intermediate range is over $100 \mathrm{cfu} / \mathrm{ml}$ but not above $1000 \mathrm{cfu} / \mathrm{ml}$ (over 2.000 but not above 3.000 $\log _{10} \mathrm{cfu} / \mathrm{ml}$ ) and the unacceptable range is above $1000 \mathrm{cfu} / \mathrm{ml}$ (above $3.000 \log _{10} \mathrm{cfu} / \mathrm{ml}$ ) [27]. Only 80 (40\%) out of a total 200 retail chicken samples that were purchased fell under the acceptable range for E. coli counts. $76 \%$ of samples fell under the unacceptable range for total coliforms. As shown in Tables 1 and 2 supermarkets had the highest percentage of samples within acceptable food safety ranges while average counts of samples from the rest of the retail outlets were within marginal or unacceptable counts of above $2.000 \log _{10} \mathrm{cfu} / \mathrm{ml}$. There was a statistical significant difference in the $E$. coli count $(\mathrm{F}(4,175)=16.676 ; \mathrm{MSE}=106.576 ; \mathrm{p}<0.001)$ and coliform counts $(\mathrm{F}(4,179)=18.37$; $\mathrm{MSE}=105.097$; $\mathrm{p}<0.001$ ) among the outlets with supermarkets having the lowest $E$. coli and coliform count compared to the rest. Graphical evidence of the differences of E. coli and coliform counts observed in the different retail outlet classifications are also shown in Figures 1 and 2.

\section{Prevalence of antimicrobial resistant $E$. coli isolated from raw retail chicken}

Seventy five percent (117 out 156) of the E. coli isolated exhibited resistance to at least one of the 12 antibiotics tested. As seen in Table 3, prevalence of antimicrobial resistance was highest for tetracycline followed by sulphamethoxazole-trimethoprin, ampicillin and streptomycin. Only $24.5 \%$ of the isolates were fully sensitive to all antibiotics while $42.9 \%$ were resistant to 3 or more antibiotics especially to the above mentioned antimicrobials. There was no significant difference in the prevalence of antimicrobial resistance among the 5 classifications of 
Table 1 Descriptive statistics of microbiological count of raw chicken meats from 5 different classifications of retail outlets

\begin{tabular}{|c|c|c|c|c|c|c|}
\hline \multirow[b]{2}{*}{ Bacteria } & \multirow[b]{2}{*}{ Summary statistics } & \multicolumn{3}{|c|}{ Total count $\log _{10} \mathrm{CFU} / \mathrm{ml}$ of carcass rinse } & \multirow[b]{2}{*}{ L.M.I butcheries } & \multirow[b]{2}{*}{ L.I.A butcheries } \\
\hline & & Supermarkets & H.I.A butcheries & H.M.I butcheries & & \\
\hline \multirow[t]{5}{*}{ E.coli } & Average $\log _{10}$ & 0.9376 & 2.6510 & 5.0007 & 4.8084 & 4.9882 \\
\hline & Median & 0.9031 & 1.7243 & 6.0000 & 5.9031 & 6.0792 \\
\hline & SD & 0.6794 & 2.3638 & 2.8155 & 2.5910 & 3.1096 \\
\hline & Minimum & 0.0000 & 0.0000 & 0.0000 & 1.0410 & 0.0000 \\
\hline & Maximum & 2.1460 & 8.0000 & 8.0790 & 8.0000 & 8.0000 \\
\hline \multirow[t]{5}{*}{ Coliforms } & Average $\log _{10}$ & 1.7239 & 5.0769 & 6.1855 & 5.2953 & 6.0111 \\
\hline & Median & 1.5315 & 6.0000 & 7.5374 & 6.0000 & 7.0731 \\
\hline & SD & 1.3324 & 2.9304 & 2.3052 & 2.5475 & 2.6770 \\
\hline & Minimum & 0.6990 & 0.9030 & 0.3420 & 1.1760 & 0.4770 \\
\hline & Maximum & 8.0000 & 8.0790 & 8.1610 & 8.0000 & 8.1760 \\
\hline
\end{tabular}

H.I.A butcheries-High income area butcheries, H.M.I butcheries-High-middle income area butcheries.

L.M.I- Low-middle income area butcheries, L.I.A- Low income area butcheries.

retail outlets $\left(x^{2} n-1=4.178 ;\right.$ d. $\left.f=4 ; p=0.382\right)$. However, samples from supermarkets had the highest prevalence (84.6\%) while samples from outlets in low income areas had the lowest prevalence of antimicrobial resistance (62.5\%).

Prevalence of $E$. coli isolates harboring virulence markers Of the $E$. coli isolated from raw retail chicken meat, $40.4 \%$ carried at least one of 10 virulence genes tested and specific for 5 known diarrheagenic E. coli. Of the $E$. coli positive for virulence genes in this study, ETEC was the most common pathogenic E. coli (61\%) while the least common was EAggEC (5\%) (Table 4).

\section{Conclusion}

The E. coli contamination rate observed in this study was almost similar to that observed in studies conducted in other developing countries. For instance, contamination rates of $98 \%$ were observed in the north east part of India, $100 \%$ in Cameroon and $100 \%$ in Vietnam [28-30]. Similar high recovery rates have been observed in studies from developed countries with contamination rates as high as $100 \%$ in Japan, $89 \%$ Minnesota, U.S.A, and $90 \%$ in two states in Australia [31-34]. Similarly, studies in Hanoi, Vietnam, Morocco and some states in America have shown that the percentage of retail chicken samples which fall under the unacceptable food safety range were also high and that perishable produce items, including poultry, available in markets in low-socio economic status census tracts had higher microbial indicator counts compared to markets in high-socio economic status due to a higher prevalence of food safety violations $[30,35-37,16,17]$. The results observed in this study might be due to factors common in Nairobi such as home slaughter of chicken by small scale poultry producers instead of slaughter at private or municipal government approved chicken slaughter houses thus increasing the potential risks for contamination due to bio-security flaws [13]. All samples from supermarkets and a majority of samples from high income butcheries were products of government approved private chicken slaughter houses. Majority of carcasses in Nairobi tend to be lumped together in one large container or sack as they are being transported in ambient temperature thus exposing them to the open air as well as allowing transfer of contaminants from one carcass to another and subsequent microbial

Table 2 Assessment of Microbial count results of raw chicken meat from the different retail markets

\begin{tabular}{|c|c|c|c|c|c|c|}
\hline \multicolumn{7}{|c|}{ Assessment of microbial counts $\log _{10} \mathrm{cfu} / \mathrm{ml}$} \\
\hline \multirow[b]{2}{*}{ Retail outlet } & \multicolumn{2}{|c|}{$\%$ acceptable samples } & \multicolumn{2}{|c|}{ \% marginal samples } & \multicolumn{2}{|c|}{$\%$ unacceptable samples } \\
\hline & E.coli & Coliforms & E.coli & Coliforms & E.coli & Coliforms \\
\hline Supermarket & $97 \%$ & $84 \%$ & $3 \%$ & $13 \%$ & $0 \%$ & $3 \%$ \\
\hline H.I.A butcheries & $69 \%$ & $26 \%$ & $10 \%$ & $15 \%$ & $21 \%$ & $59 \%$ \\
\hline H.M.I butcheries & $29 \%$ & $7 \%$ & $12 \%$ & $14 \%$ & $60 \%$ & $79 \%$ \\
\hline L.M.I butcheries & $25 \%$ & $10 \%$ & $10 \%$ & $20 \%$ & $65 \%$ & $70 \%$ \\
\hline L.I.A butcheries & $16 \%$ & $33 \%$ & $6 \%$ & $6 \%$ & $78 \%$ & $61 \%$ \\
\hline
\end{tabular}




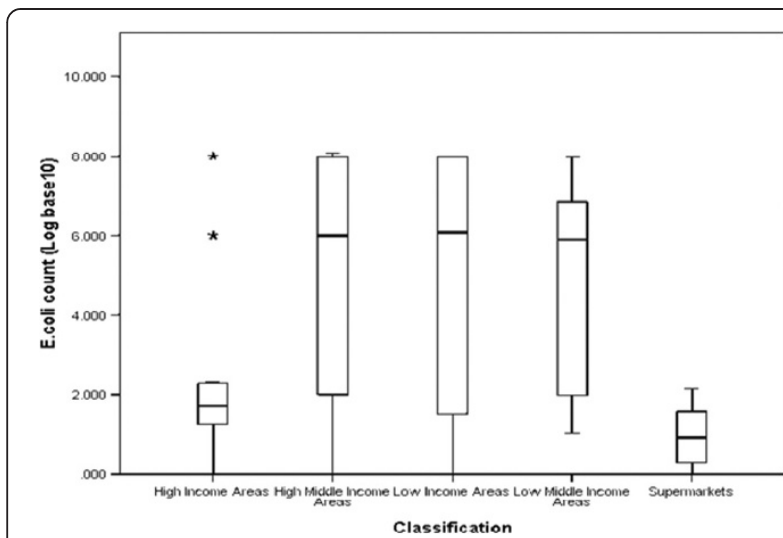

Figure 1 Distribution of $E$. coli count among the 5 retail outlet classifications. Counts were evenly distributed., the size of the boxes for high- middle income, low-middle income and low income areas indicate that the middle 50\% E. coli counts are spread out for these groups while for high class butcheries and supermarkets the box sizes indicate that the middle $50 \%$ of the counts are clumped together.

multiplication. Studies in Iran and Switzerland showed that there were significant differences in contamination rates between individually packed and unpacked chicken meat samples [38,39]. Use of freezers and cooling temperatures for storage and display in some outlets from high middle income and low income areas could have resulted to few samples falling under the acceptable food safety range in these outlets as seen from the outliers in Figure $1[40,41]$. In most retail outlets, the degree of physical contact between different kinds of meat on display such as beef, fish and mutton may have led to cross contamination of different meats. Also, use of bare hands in handling meat, utensils and money at the same time as observed may have increased chances of microbial contamination [42]. In contrast to the findings in this study, a similar recent

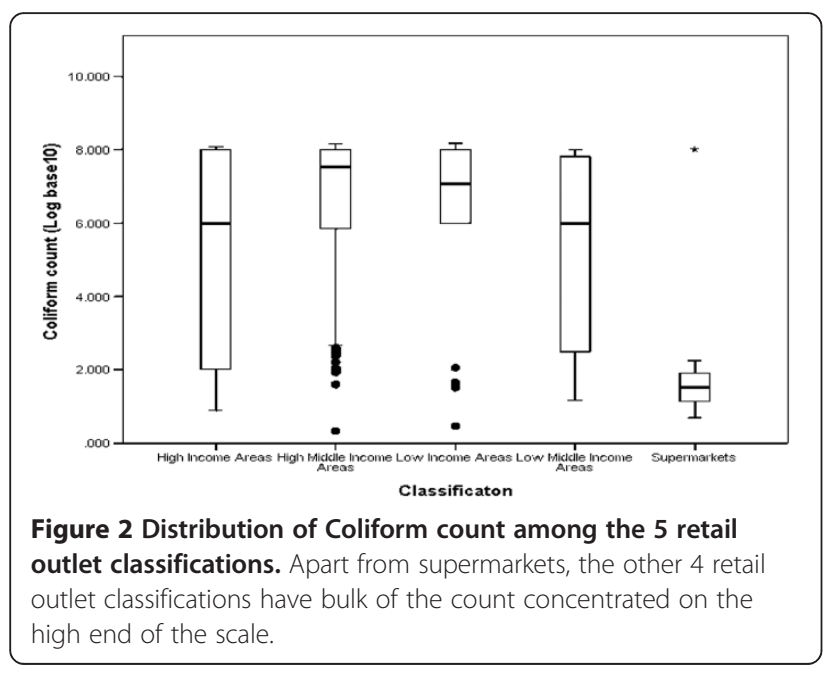

Table 3 Antimicrobial resistance profiles among $E$. coli isolated in retail chicken meat $(n=156)$

\begin{tabular}{lll}
\hline Antibiotic & Frequency of resistant isolates & $\%$ \\
\hline AMC & 4 & 2.6 \\
SXT & 77 & 49.4 \\
TE & 94 & 60.3 \\
AMP & 53 & 34 \\
CIP & 7 & 4.5 \\
CAZ & 0 & 0 \\
K & 8 & 5.1 \\
S & 47 & 30.1 \\
CRO & 18 & 11.5 \\
CN & 1 & 0.6 \\
NA & 23 & 14.7 \\
C & 21 & 13.5 \\
\hline
\end{tabular}

study in Accra, Ghana found that even though hygienic conditions in supermarkets were generally better than those in local markets and farms, there was no significant difference between the microbial counts for these retail outlets and they all had low microbial counts [43]. The authors attributed this observation to the deliberate efforts by the food sector in improving the hygienic procedures in the processing of poultry over the years.

Similar prevalence of antibiotic resistance in E. coli isolated from retail chicken have been observed in other studies ranging from $40.6 \%$ in Japan, $52 \%$ in Iceland, $84.6 \%$ in Minneapolis, U.S.A, $83.8 \%$ in Vietnam and even $100 \%$ isolates in Senegal being resistant to one or more antibiotics [31,44-47]. The high prevalence of resistance in poultry meat isolates is alarming given the evidence of possible transmission of antibiotic resistant food borne bacteria to consumers and food handlers [48]. Similar multi-drug resistance phenotypes of E. coli isolated from retail chicken have been reported in studies conducted in Japan, Vietnam, Saudi Arabia and Slovakia [30,31,49,50]. The common resistance phenotypes observed are of great clinical significance since these antimicrobials are considered to be among the frontline therapeutic drugs for treatment of most bacterial infections in

Table 4 Classification of pathogenic $E$. coli identified from retail chicken meat

\begin{tabular}{lll}
\hline Classification of pathogenic $\boldsymbol{E}$. coli & Frequency of isolates & $\%$ \\
\hline EPEC & 13 & 20.6 \\
ETEC & 38 & 60.3 \\
EIEC & 4 & 6.3 \\
EaggEC & 3 & 4.8 \\
STEC & 5 & 7.9 \\
\hline
\end{tabular}


humans in Kenya. Past studies assessing antimicrobial consumption in food producing animals in Kenya showed that tetracyclines, sulphonamides and trimethoprins, nitrofurans, aminoglycosides, beta lactams and the quinolones were the most commonly used drugs in food producing animals with tetracyclines and sulphonamides/trimethoprin topping the list in popularity and accounting for nearly $78 \%$ of the use [51]. A corresponding study in Tanzania showed similar results supporting these findings [52]. Such use has been shown to result in the development of resistant bacteria which can then reach heavily exposed individuals such as slaughter house workers, food handlers and farmers who feed the animals with the antimicrobials [53]. These resistant bacteria can then easily contaminate the carcasses of food animals along the production line to the retail outlets. In countries such as Uganda and Iceland, studies have shown that broiler chicken production has been associated with a high prevalence of antimicrobial resistance in isolates from these chickens due to consumption of antimicrobials [54,55]. In this study, all samples from supermarkets, which had more resistant isolates, came from improved breeds of chicken/broilers while $80 \%$ of samples from low income areas were from local/indigenous chicken breeds. A common practice for broiler chicken producers in urban areas in Kenya is to add antibiotics into the commercial feeds or drinking water for chicken thus exposing them more to undue antimicrobial consumption [56]. This practice may modify the intestinal flora and create a selective pressure in favor of resistant bacteria [57]. On the other hand, indigenous chicken production in most African countries including Kenya is traditionally based on free range breeding systems allowing birds to grow without any external influence. They are estimated to reach a mature, marketable age by 8 months $[42,58]$.

Studies done in Burkina Faso, Korea and Lebanon also showed presence of $E$. coli contaminants harboring virulence genes in fresh poultry meat (with prevalence of $43 \%, 14 \%$ and $14 \%$ respectively) and that that ETEC, EPEC and STEC were the most common diarrheagenic E. coli detected [59-61]. This could be because ETEC, EPEC and STEC are much frequently implicated in various food and water borne diseases and they are known contaminants of meat and meat products $[62,63]$. Studies, for instance in Canada, Spain and Minnesota U.S.A, have also shown that live chicken and other food animals are known reservoirs of these pathogenic E. coli and therefore contamination could actually be from the animal during evisceration or even from water used during their processing [64-66]. On the other hand EIEC and EaggEC are not implicated much in food and water borne illnesses and there are no known animal reservoirs for these pathogens hence any primary source of contamination appears to be infected humans [63,67]. Another reason for this observation in this study is that ETEC had several virulent gene markers compared to the rest and thus could be easily detected more than the others. These results are important as they indicate that apart from being highly contaminated with coliforms which could lead to quick spoilage, raw retail chicken in Nairobi, Kenya is a potential source of food borne illnesses as it carries pathogenic E. coli. This has important implications and present unique challenges for interventions for microbial contamination of retail chicken meats in urban settings.

\section{Competing interests}

The authors declare that they have no competing interest.

\section{Authors' contributions}

JA was the main author, who participated in conception of the study and study design, literature search, acquisition of data, statistical analysis and drafting of the manuscript. SK was involved in supervising, designing and coordinating the study, interpreting the data and critical revision and drafting of the manuscript. GK participated in supervision, study design and development of the manuscript. JNK greatly contributed in statistical analysis and data interpretation. All authors read and approved the final manuscript.

\section{Acknowledgments}

The authors would like to acknowledge personnel of KEMRI, Centre of Microbiology Research, Enterics laboratory for their technical assistance and co-operation and the Director, KEMRI for permission to publish. This work was funded by a joint WHO/FAO pilot projects grant.

\section{Author details}

'Institute of Tropical Medicine and Infectious Diseases, Jomo Kenyatta University of Agriculture and Technology, P.O Box 62000-00200, Nairobi, Kenya. ${ }^{2}$ Centre for Public Health Research, Kenya Medical Research Institute, P.O Box 20752-00202, Nairobi, Kenya. ${ }^{3}$ Centre for Microbiology Research, Kenya Medical Research Institute, P.O Box 43640-00100, Nairobi, Kenya.

Received: 1 February 2014 Accepted: 6 September 2014

Published: 10 September 2014

\section{References}

1. Lindqvist $R$, Anderson $Y$, De Jong B, Norberg P: A summary of reported food borne disease incidents in Sweden, 1992 to 1997. J Food Protect 2000, 63:1315-1320.

2. Su HP, Chu SI, Tsai JL, Lee CL, Pan TM: Bacterial food borne illness outbreaks in Northern Taiwan, 1995 to 2001. J Infect Chem 2005, 11:146-151.

3. Lynch M, Painter J, Woodruff R, Braden C: Surveillance of food borne disease outbreaks in United States, 1998 to 2002. Morbidity Mortality Wkly Rep Surveil Summaries/CDC 2006, 55:1-34.

4. Fratamico PM, Bhunia AK, Smith JL: Food borne pathogens. In Microbiology and Molecular biology. Wymondham, Norfolk: Caster academic press; 2005:273.

5. Pertersen KE, James WO: Agents, vehicles and causal inference in bacterial food borne disease outbreaks, 1986 to 1995. J Am Vet Med Assoc 1998, 212:1874-1881.

6. Todd A: Epidemiology of food borne diseases. World Health Stat 1997, $50: 1-2$

7. Tauxe RV: Emerging food borne diseases: an evolving public health challenge. Emerg Infect Dis 1997, 3:425-434.

8. Costa D, Poeta P, Saenz Y, Coelho AC, Matos M, Vinue' L: Prevalence of antimicrobial resistance and resistance genes in faecal Escherichia coli isolates recovered from healthy pets. Vet Microbiol 2008, 127:97-105.

9. Belluck P: Federal inspectors seek source of Escherichia coli contamination. In New York Times. 1997:1. 
10. Borche $E$, Arinder P: Bacteriological safety issues in beef and ready to eat meat products as well as control measures. Meat Sci 2002, 62(3):381-390.

11. Andrea W: Mobile slaughter houses will help small farmers. In News observer. 2010:3.

12. Selvan PR, Narendra B, Sureshkumar S, Venkatamanujam V: Microbial quality of retail meat products available in Chennai city. Am J Food Technol 2007, 2(1):55-59.

13. O'Brien TF: Emergence, spread, and environmental effect of antimicrobial resistance: how use of an antimicrobial anywhere can increase resistance to any antimicrobial anywhere else. J Clin Infect Dis 2002, 34(3):78-84.

14. Angulo FJ, Nargund VN, Chiller TC: Evidence of an association between use of anti-microbial agents in food animals and anti-microbial resistance among bacteria isolated from humans and the human health consequences of such resistance. J Vet Med 2004, 51:374-379.

15. Molbak K: Spread of resistant bacteria and resistance genes from animals to humans - the public health consequences. J Vet Med 2004, 51:364-369.

16. Algert SJ, Agrawal A, Lewis DS: Disparities in access to fresh produce in low income neighborhoods in Los Angeles. Am J Prev Med 2006, 30:365-370

17. Moore LV, Diez-Roux AV: Associations of neighborhood characteristics with the location and type of food store. Am J Publ Health 2006, 96:325-331.

18. Kikuvi GM, Ole-Mapenay IM, Mitema ES, Ombui JN: Antimicrobial resistance in Escherichia coli isolates from faeces and carcass samples of slaughter cattle, swine and chickens in Kenya. Israel J Vet Med 2006, 61(3-4):82-88

19. Afullo A, Odhiambo F: The primary solid waste storage gaps experienced by Nairobi households. Ethiop J Environ Manag 2009, 2:3

20. K'Akumu OA, Olima WHA: The dynamics and implications of residential segregation in Nairobi. Habitat Int J 2007, 31:87-99.

21. AOAC: Official methods 966.24 for enumeration of Escherichia coli and Coliform bacteria in raw meats. 2006. http://www.3M.com/microbiology.

22. MacFaddin JF: Biochemical Tests for Identification of Medical Bacteria. Philadelphia: Lippincott Williams and Wilkins; 2000. 3:363-36.

23. Bauer AW, Kirby WMM, Sherris JC, Turk M: Antibiotic susceptibility testing by a standardized single disk method. Am J Clin Path 1966, 45:493-496.

24. Clinical and Laboratory Standards Institute, CLSI: Performance Standards for Antimicrobial Susceptibility Testing. Twenty-second Informational Supplement. M100-S22. Clinical and Laboratory Standards Institute. Wayne, PA: CLSI; 2012. Document M100-S22.

25. Ehrt S, Schnappinger D: Isolation of plasmids from $E$. coli by alkaline lysis: Methods in molecular biology. Springer Protocols 2003, 235:75-78.

26. Fujioka M, Kasai K, Miura T, Sato T, Otomo Y: Rapid diagnostic method for the detection of diarrheagenic Escherichia coli by multiplex PCR. Jpn J Infect Dis 2009, 62:476-480.

27. Food Safety and Inspection Service: Guidelines for Escherichia coli testing for process control verification in poultry slaughter establishment: HACCP guidelines and policies. 1996. http://www.fsis.usda.gov/wps/portal/ fsis/topics/regulatorycompliance/compliance-guides-index\#Ecoli.

28. Saikia P, Joshi SR: Retail market poultry meats of North-East India: a microbiological survey for pathogenic contaminants. Res J Microbiol 2010, 5(1):36-43.

29. Nzouankeu A, Ngandjia A, Ejenguele G, Njine T, Wouafo MH: Multiple contaminations of chickens with Campylobacter, Escherichia coli and Salmonella in Yaoundé, Cameroon. J Infect Dev Ctries 2010, 4(9):583-586.

30. Thangh Huong CT, Hai Duong NT, Thu Hien NT: Contamination of some bacteria isolated from chicken meat in retail markets in Hanoi and examination of the antibiotic resistance ability of Salmonella and E. coli strains isolated. J Sci Dev 2009, 7(2):181-186.

31. Ashraf MA, Hirofumi S, Tadashi S: Isolation and molecular characterization of multidrug resistant strains of Escherichia coli and Salmonella from retail chicken meat in Japan. J Food Sci 2009, 74:7.

32. Johnson JR, Murray AC, Gajewski A, Sullivan M, Snippes P, Kuswoski MA Smith KE: Isolation and molecular characterization of Nalidixic acid resistant extra intestinal pathogen Escherichia coli from retail chicken products. Antimicrob Agents Chemother 2003, 7:2161-2168.

33. Zhao S, Blickenstaff K, Bodeis-Jones S, Gaines SA, Tong E, McDermott PF: Comparison of the prevalence and antimicrobial resistances of Escherichia coli isolates from different retail meats in the United States, 2002 to 2008. J Food Microbiol 2012, 78:23.
34. Pointon A, Sexton M, Dowsett P, Saputra T, Kiermeier A, Lorimer M: A baseline survey of the microbiological quality of chicken portions and carcasses at retail in two Australian States, 2005 to 2006. J Food Protect 2008, 71(6):1123-1134.

35. Amara A, Ziani Z, Bouzoubaa K: Antibiotic resistance of Escherichia coli strains isolated in Morocco from chickens with coccilobacillosis. Vet Microbiol 1995, 43:325-330.

36. Koro ME, Anandan S, Quinlan JJ: Microbial quality of food available to populations of differing socio economic status. Am J Prev Med: Elsevier Inc 2010, 20(10):30.

37. Chaiba A, Rhazifilali F, Chahlaoui A, Soulaymani Bencheikh R, Zerhouni M: Microbiological quality of poultry meat on the Meknes market (Morocco). Inter J Foodsaf 2010, 9:67-71

38. Vaskas TA, Dahesht EA, Seifi S, Rahmani M, Motaghifar A, Safanavaee R: Study and comparison of the bacterial contamination outbreak of chicken meat consumed in some cities of Mazandaran province, Iran. Afr J Microbiol Res 2012, 6(33):6286-6290.

39. Regula G, Ursula L, Roger S, Danuser J: Risk factors for antibiotic resistance in campylobacter species isolated from raw retail poultry in Switzerland. BioMed Central: Publ Health 2003, 3:39

40. Jakabi M, Gelli DS, Ristiri CA, De Paula AMR, Sakuma H, Lopez GIS: Presence of Salmonella species and Escherichia coli 0157:H7 in raw meat in Sao Paolo city, Brazil and evaluation of low temperature (refrigeration and freezing) in resistance of these bacteria. In Determination of human pathogen profiles in food by quality assured microbial assays. Paper presented at the proceedings of a final research coordination meeting held in Mexico city, Mexico. Edited by Loaharanu P, Rubio T. 2002:35-42.

41. Popkin BM: Technology, transport, globalization and the nutrition transition food poultry. J Food Poult 2006, 10:1016.

42. Nyaga P: Good bio-security practices in small scale commercial and scavenging production systems in Kenya. http://www.fao.org/docrep/013/ al838e/al838e00.pdf.

43. Adu-Gyamfi A, Torgby-Tetteh W, Appiah V: Microbiological quality of chicken sold in Accra and determination of D10-value of E. coli. J Food Nutri Sci 2012, 3:693-698.

44. Thorsteinsdottir TR, Haraldsson G, Fridriksdottir V, Kristinsson KG, Gunnarsson E: Prevalence and genetic relatedness of antimicrobial resistant Escherichia coli isolated from food animals, food and humans in Iceland. Zooneses Publ Health 2010, 57:189-196.

45. Van $T \mathrm{TH}$, George M, Istivan T, Tran L, Cole PJ: Antibiotic resistance in food-borne bacteria contaminants in Vietnam. App Environ Microbiol 2007, 73(12):7906-7911.

46. Johnson JR, Kuskowski MA, Smith K, O'Bryan TT, Tatini S: Antimicrobial resistant and extra intestinal pathogenic Escherichia coli in retail foods. J Infect Dis 2005, 191:1040-1049.

47. Fofana A, Bada AR, Seydi M, Akakpo AJ: Antibiotic resistance of Escherichia Coli strains isolated from raw meat in Senegal. Dakar Med 2006, 51(3):145-150.

48. Bester LA, Essack SY: Antibiotic resistance via the food chain: Fact or fiction? S Afri J Sci 2010, 106(9/10):1-5.

49. Al-Ghamdi SA, El-Morsy F, Al-Mustafa ZH, Al-Ramadhan M, Hanif M: Antibiotic resistance of Escherichia coli isolated from poultry workers, patients and chicken in the eastern province of Saudi Arabia. J Trop Med Intern Health 1999, 4(4):278-283.

50. Ruzauskas M, Šiugždinienè R, Šeputienè V, Sužiedèlienẻ V, Virgailis M, Daugelavičius $S$ : The situation of antimicrobial resistance of enteric bacteria isolated from animal origin to quinolones and fluoroquinolones. Veterinarijairzootechnika 2010, 50:73-80.

51. Mitema ES, Kikuvi GM, Wegener HC, Stohr K: An assessment of antimicrobial consumption in food producing animals in Kenya. $J$ Vet Pharm 2001, 24(6):385-390.

52. Nonga HE, Mariki M, Karmurbo ED, Mdegela RH: Assessment of antimicrobial usage and antimicrobial residues in broiler chickens in Morogoro municipality, Tanzania. Pakistan J Nutr 2009, 8(3):203-207.

53. Hammerum AM, Heuer OE: Human health hazards from antimicrobial resistant Escherichia coli of animal origin. J Clinic Infect Dis 2009, 48:916-921.

54. Majalija S, Oweka F, Wito GS, Lubowa M, Vudriko P, Nakamaya FM: Antibiotic susceptibility profiles of faecal Escherichia coli isolates from dip-litter broiler chickens in Northern and Central Uganda. J Vet Res 2010, 3(4):75-80.

55. Thorsteinsdottir TR, Haraldsson G, Fridriksdottir V, Kristinsson KG, Gunnarsson $\mathrm{E}$ : Broiler chickens as source of human Fluoroquinolone resistant Escherichia coli, Iceland. J Emerg Infect Dis 2010, 16(1):133-135. 
56. Kariuki $S$, Onsare R, Mwituria J, Ngetich R, Nafula C, Karimi K, Karimi $P$, Njeruh F, Irungu P, Mitema E: Improving food safety in meat value chains in Kenya. General interest paper: FAO/WHO project report. Food Protect Trend 2013, 5:172-179.

57. Diarra MS, Silversides FG, Diarrassouba F, Pritchard J, Masson L, Brousseau R: Impact of feed supplementation with antimicrobial agents on growth performance of broiler chickens, Clostridium pefringens and Enterococcus counts and antibiotic resistance phenotypes and distribution of antimicrobial resistance determinants in Escherichia coli isolates. App Environ Microbiol 2007, 73(20):6566-6576.

58. Upton M: The role of livestock in economic development and poverty reduction. http://www.fao.org/ag/againfo/programmes/en/pplpi/docarc/ wp10.pdf.

59. Kagambega A, Martikainen O, Lienemann T, Siitonen A, Traore AS, Barro N, Haukka K: Diarrheagenic Escherichia coli detected by 16-plex PCR in raw meat and beef intestines sold at local markets in Ouagadougou, Burkina Faso. Intern J Food Microbiol 2012, 153(1-2):154-158.

60. Lee GY, Jang HI, Hwang ZG, Rhee MS: Prevalence and classification of pathogenic Escherichia coli isolated from fresh beef, poultry and pork in Korea. Internat J Food Microbiol 2009, 134(3):196-200.

61. El-Rami FE, Rahal EA, Sleiman FT, Abdolnoor AM: Identification of virulence genes among antibacterial resistant Escherichia coli isolated from poultry. Adv Stud Biol 2012, 4(8):385-396.

62. CDC: Escherichia coll: General information. http://www.cdc.gov/ecoli/general/.

63. Feng P, Stephen DW Jinneman K: Diarrheagenic Escherichia coli: Bacteriological analytical manual. http://www.fda.gov/food/ foodscienceresearch/laboratorymethods/ucm070080.htm.

64. Bergeron CR, Prussing C, Boerlin P, Daignault D, Dutil L, Reid-Smith R: Chicken as reservoir for extra-intestinal pathogenic Escherichia coli in humans, Canada. J Emerg Infect Dis 2012, 18:3.

65. Cortés P, Blanc V, Mora A, Dahbi G, Blanco JE, Blanco M: Isolation and characterization of potentially pathogenic antimicrobial-resistant Escherichia coli strains from chicken and pig farms in Spain. Appl Environ Microbiol 2010, 76:2799-2805

66. Johnson JR, Sannes MR, Croy C, Johnston B, Clabots C, Kuskowski MA: Antimicrobial drug-resistant Escherichia coli from humans and poultry products, Minnesota and Wisconsin, 2002-2004. Emerg Infect Dis 2007, 13:838-846

67. Smith H, Willshaw G, Cheasty T: E. coli as a cause of out breaks of diarrhoeal disease in the U.K. Microbiol Today 2004, 31:117-118.

doi:10.1186/1756-0500-7-627

Cite this article as: Odwar et al:: A cross-sectional study on the microbiological quality and safety of raw chicken meats sold in Nairobi, Kenya. BMC Research Notes 2014 7:627.

\section{Submit your next manuscript to BioMed Central and take full advantage of:}

- Convenient online submission

- Thorough peer review

- No space constraints or color figure charges

- Immediate publication on acceptance

- Inclusion in PubMed, CAS, Scopus and Google Scholar

- Research which is freely available for redistribution 